\title{
The Influence of Personal Value, Moral Philosophy, and Organizational Ethical Culture on Auditor Action and Acceptance for Dysfunctional Behavior
}

\author{
Sanda Patrisia Komalasari ${ }^{1 *}$, Rahmat Febrianto ${ }^{1}$, Yurniwati ${ }^{1}$ and Nilam Kemala Odang \\ \{sandapatrisia@gmail.com* ${ }^{*}$ \\ ${ }^{1}$ Accounting Departement,Andalas University Padang, Indonesia
}

\begin{abstract}
Objectives of this research are to investigate the effect of organizational ethical culture, personal values, and moral philosophy on auditor actions and acceptance for dysfunctional behaviour. This research also seeks to investigate the effect of organizational ethical culture through personal values and moral philosophy on auditor actions and acceptance for dysfunctional behaviour and effect of personal auditor value on his moral philosophy. By using structural equation modeling technique from survey result 52 auditor resulted that auditor which tend to have moral philosophy of idealism and not relativism is auditor having personal value of conservatism and self-enhancement. While auditor who tend to relativism is auditor who have a personal value of openness to change. Auditor who have a moral philosophy of relativism will tend to accept dysfunctional behavior, while the idealism auditor will tend to reject such behavior. Organizational ethical culture and personal value of self-enhancement are found have an effect on the auditors acceptance for dysfunctional behavior. Only an ethical culture is an ethical environment that affects auditor dysfunctional action. The personal value of conservatism through the moral philosophy of idealism founded have an effect on auditor acceptance for dysfunctional behavior, but not for organizatonal ethical culture through personal value and moral philosophy.
\end{abstract}

Keywords: Organizational ethical culture, personal values, moral philosophy, dysfunctional acts in auditing, auditor acceptance for dysfunctional behavior

\section{Introduction}

Auditor dysfunctional behaviour is a continuous concern by AICPA. It's a deviant behaviour performed by auditors in conducting audit. This behaviour may degrade audit quality, both directly and indirectly (Satava, Caldwell and Richards, 2006). The result of the study shown that auditors' dysfunctional behaviour continued to occur all the times in various countries (Otley and Pierce, 1996; Satava, Caldwell and Richards, 2006). The problems of dysfunctional actions that are allowed to extend could tarnish the reputation of auditor profession. Auditors play the role as gatekeepers in monitoring relevant information related to decision making by clients and auditors are also obliged to always fulfil their responsibilities professionally (Schwartz and Bilsky, 1987). It is very important for auditors to align their actions with the highest ethical standards (Donnelly, Quirin and O'Bryan, 2003). This means that it's very important for auditors to don't act or accept dysfunctional actions.

There are many obstacles influenced decision makers, to do the right thing or ethically. These factors can be grouped into organizational and personal characteristics constraints (Dirsmith and Covaleski, 1985). Personal characteristics that may affect the auditors' actions 
and acceptance of dysfunctional behaviour are moral philosophy and personal value, then organizational characteristics factors are the ethical culture of organization.

In the 1980s, organizational culture was identified as potential element in organizational success (Schwartz, 1992). Ethical culture is a part of an organizational culture that consist of various controls, formal and informal, that encourage ethical or unethical behaviour. If ethical behaviour is reinforced by organizational culture, ethical behaviour will increase within the organization (Zarei, Esmaeeli and Zarei, 2016). The result of the study shown that there is an effect of ethical culture on auditors' ethical judgements (Treviño, Butterfield and McCabe, 1998; Suhayati, 2012; Aprilia and Pangestuti, 2017).

Ethical culture can be a powerful tool for organizational leaders to communicate organizational values to all members. Therefore, organizational members can act ethically as expected by the organization (Aprilia and Pangestuti, 2017). However, no matter how strong the ethical culture of the organization is, it won't succeed in guiding the auditor individually if the auditor himself don't want to be guided by the culture. Rigorous regulations aren't the only way to overcome the auditor's actions and acceptance of dysfunctional behaviour. The real determining factors whether an auditor will act or accept dysfunctional actions are determined by auditors themselves. Personal values and certain moral philosophies are personal characteristics that can distinguish an auditor from other auditors.

Personal value is a set of beliefs that guide a person in acting. A person will act not only because of stimuli, but also based on their beliefs. It means that the auditor won't act or accept dysfunctional actions if it's not in accordance with the value he has. Some research shown that the personal values affect somebody's actions (Fogarty, 1992; Hunt and Vitell, 2006; Sweeney, Pierce and Arnold, 2013).

Auditor behaviour will be in accordance with the ethical standards of the organization, only if the auditor is in the right ethical scale position, as expected by the organization. If the moral compass of auditor has diverged, there is no law that strong enough to prevent the act of deviation he did. The individual's ethical code will represent the last line of devense to prevent auditor's actions and acceptance of dysfunctional behaviour. Moral philosophy is a key factor in determining how ethical choices will be made by a person (Rallapalli, Vitell and Szeinbach, 2000; Karim et al., 2015).

Moral philosophy of somebody can be influenced by his personal values. Auditors' personal value preference is a manifestation of their moral philosophy which will influence their ethical beliefs and actions. Some ethical decision making models consider personal value as an antecedent to a more general moral view. Its strength will influence the reasoning process associated with ethical issues (Rallapalli, Vitell and Szeinbach, 2000; Schein and Schein, 2006; Svanberg and Öhman, 2013).

Personal values and moral philosophy aren't a part of standard equipment when somebody is born. He was born without value or moral philosophy. Through the process of socializing, it's influenced by the rules and cultural norms in his environment. Socialization as a process of individuals are formed by the community where they live (Forsyth, 2013). Individuals form themselves in response to their environmental demands and give an incentive to adopt attributes which appropriate to environment. Given an organizational ethical culture, an auditor may be able to change his personal values and moral philosophy to fit the beliefs/values held by organization.

Based on explanation above, known that organizational ethical culture, personal values, moral philosophy, and auditor actions and acceptance for dysfunctional behavior can have interrelationships. Organizational ethical culture may be able to change the auditor's personal values, then his moral philosophy, and then his actions so as not to act or accept dysfunctional 
actions. Because of that the objectives of this study are (1) to investigate the effect of organizational ethical culture, personal values, and moral philosophy on auditor actions and acceptance of dysfunctional behaviour, (2) to investigate the effect of organizational ethical culture through personal values and moral philosophy on auditor actions and acceptance of dysfunctional behaviour, and (3) to investigate the effect of personal auditor value on his moral philosophy.

As an effort to prevent auditor actions and acceptance for dysfunctional behaviour, this research will provide an approach that can be used to prevent and reduce it. This research will provide knowledge about whether an organization's ethical culture is able to change the personal values and moral philosophy of the auditors so they won't act and accept dysfunctional actions. It will be useful for the organization in determining the personal worth of the auditor candidates in recruitment. This research will provide knowledge of personal value that should be fit with moral philosophy of auditors who will reject or accept dysfunctional behaviour. In addition, this research will show the types of moral philosophy and ethical culture that will prevent and reduce auditors action and acceptance of dysfunctional behaviour.

\section{Methodology}

Sample selection process uses convenience sampling method. The data analysis tool uses partial least square-structural equation modelling (PLS-SEM), using Smart-PLS version 3.0 software. The data were obtained from questionnaire answers of 52 public sector auditors represent West Sumatera. The questionnaire consists of organization's ethical culture, personal values, moral philosophy, auditors' action for dysfunctional behaviour, and auditor acceptance for dysfunctional behaviour described as follows:

\subsection{Auditors' Dysfunctional Behavior}

Researcher uses question instruments made by Outley and Pierce (Satava, Caldwell and Richards, 2006). Alternative answers to these questions use a 5-point Likert scale, where 1 is never and 5 is almost always.

\subsection{Auditors' Acceptance Of Dysfunctional Behavior}

Researcher uses question instruments made by (Fogarty, 1992; Donnelly, Quirin and O'Bryan, 2003). The answers to these questions use 5-point Likert scale, where 1 is very disagree and 5 is very agree.

\subsection{Moral Philosophy}

This study uses a questionnaire by (Forsyth, 2013). Respondents were asked to indicate the level of their agreement on the statement items in questionnaire using a 7-point Likert scale, where 1 is totally disagree, 4 is no opinion, and 7 is completely agree.

\subsection{Personal Value}

This study uses a questionnaire by (Schwartz, 1992). Respondents were asked to indicate the level of their agreement on their personal value preference using 9-point, started from -1 until 7, where -1 is contrary with respondents' value, 0 isn't important, 1 until 7 are important. 


\subsection{Organizational Ethical Culture}

Measurement instrument used in this study based on question instruments made (Treviño, Butterfield and McCabe, 1998). Responses to questions were collected by using 6point Likert scale, where 1 is very disagree and 6 is very agree.

\section{Result}

\subsection{Reliability Test}

Table I shows the variabels in this research. Those variabels have composite reliability value $>$.7. It means that those variables fulfill requirements of reliability.

Table 1. Composite Reliability

Variables Composite Reliability

\begin{tabular}{lc}
\hline Organizational Ethical Culture & \\
\hline Ethical Environment & .880 \\
\hline Implementation of Ethical Code & .867 \\
\hline Compliance to Authority & .899 \\
\hline Personal Value & .935 \\
\hline Conservation & .885 \\
\hline Self-transcendence & .897 \\
\hline Self-enhancement & .903 \\
\hline Openness to Change & .861 \\
\hline Moral Philosophy & .909 \\
\hline Idealism & .825 \\
\hline Relativism & .819 \\
\hline Dysfunctional Actions & \\
\hline Acceptance of dysfunctional behavior &
\end{tabular}

3.2. Validity Test

\subsubsection{Convergent Validity}

Table 2 presents indicators that meet the requirements of convergent validity, i.e. the best indicators that represent their variables with outer loadings for each indicators $\geq .6$ and average variance extracted (AVE) for each variable $\geq .5$.

Table 2. Outer Loadings And Ave

\begin{tabular}{lll}
\hline Indicators & $\begin{array}{l}\text { Outer } \\
\text { Loadings }\end{array}$ & AVE \\
\hline \multicolumn{4}{l}{ Organizational Ethical Culture } & \\
\hline Ethical Environment (LE) & & .542 \\
\hline $\begin{array}{l}\text { Punishment implemented } \\
\text { (LE3) }\end{array}$ & .629 & \\
\hline $\begin{array}{l}\text { Leaders become role } \\
\text { models who have high }\end{array}$ & .610 \\
ethical standards (LE4) & \\
\hline Award for integrity (LE5) & .737 \\
\hline The code of conduct is & .757 \\
\hline
\end{tabular}




\begin{tabular}{lll}
\hline Indicators & $\begin{array}{l}\text { Outer } \\
\text { Loadings }\end{array}$ & AVE \\
\hline $\begin{array}{l}\text { carried out accordingly } \\
\text { (LE6) }\end{array}$ & \\
\hline $\begin{array}{l}\text { The code of ethics is used } \\
\text { as a guide/norm (LE7) }\end{array}$ & .874 \\
\hline $\begin{array}{l}\text { Leader guides its members } \\
\text { in ethical decision-making }\end{array}$ & .735 \\
process (LE8) & \\
\hline $\begin{array}{l}\text { Professional ethical codes } \\
\text { are in line with informal }\end{array}$ & .647 \\
norms (LE9) & \\
\hline $\begin{array}{l}\text { Implementation of Ethical } \\
\text { Code (IKE) }\end{array}$ & \\
\hline $\begin{array}{l}\text { Required to read and } \\
\text { understand ethical codes }\end{array}$ & .838 \\
(IKE1) & \\
\hline $\begin{array}{l}\text { Given the tools to consult } \\
\text { about ethical codes (IKE2) }\end{array}$ & .869 \\
\hline $\begin{array}{l}\text { Auditors are expected to } \\
\text { be able to assess and } \\
\text { decide on their actions in }\end{array}$ & \\
accordance with ethical \\
codes (IKE4)
\end{tabular}




\begin{tabular}{|c|c|c|}
\hline Indicators & $\begin{array}{l}\text { Outer } \\
\text { Loadings }\end{array}$ & AVE \\
\hline Social acceptance (PD10) & .756 & \\
\hline $\begin{array}{l}\text { Ambitious, hardworking, } \\
\text { and aspiring (PD3) }\end{array}$ & .843 & \\
\hline Can control others (PD6) & .769 & \\
\hline Wealth (PD8) & .932 & \\
\hline $\begin{array}{l}\text { Openness to change } \\
(\text { KTP })\end{array}$ & & .701 \\
\hline Pride (KTP 6) & .827 & \\
\hline Pleasant life (KTP 7) & .686 & \\
\hline $\begin{array}{l}\text { Dare to venture and take a } \\
\text { risk (KTP 8) }\end{array}$ & .908 & \\
\hline $\begin{array}{l}\text { Life filled with challenge, } \\
\text { novelty, and change } \\
\text { (KTP9) }\end{array}$ & .909 & \\
\hline \multicolumn{3}{|l|}{ Moral Philosophy } \\
\hline Idealism (I) & & .511 \\
\hline $\begin{array}{l}\text { People make sure that the } \\
\text { actions they will take not } \\
\text { harm others (I1) }\end{array}$ & .760 & \\
\hline $\begin{array}{l}\text { Causing someone at risk is } \\
\text { an action that cannot be } \\
\text { tolerated (I2) }\end{array}$ & .602 & \\
\hline $\begin{array}{l}\text { Decisions/actions that } \\
\text { have the potential to harm } \\
\text { others is something that's } \\
\text { always wrong (I3) }\end{array}$ & .635 & \\
\hline $\begin{array}{l}\text { Someone shouldn't hurt } \\
\text { others (I4) }\end{array}$ & .672 & \\
\hline $\begin{array}{l}\text { Someone shouldn't take } \\
\text { actions that could threaten } \\
\text { the dignity and welfare of } \\
\text { others (I5) }\end{array}$ & .820 & \\
\hline $\begin{array}{l}\text { If any actions can harm } \\
\text { innocent person, that } \\
\text { action shouldn't be done } \\
\text { (I6) }\end{array}$ & .776 & \\
\hline Relativism (R) & & .627 \\
\hline $\begin{array}{l}\text { Does ethical varies from } \\
\text { one situation to another } \\
\text { (R2) }\end{array}$ & .797 & \\
\hline $\begin{array}{l}\text { Moral standards must be } \\
\text { seen individually, (R3) }\end{array}$ & .741 & \\
\hline $\begin{array}{l}\text { The difference about } \\
\text { moral cannot be fixed(R4) }\end{array}$ & .815 & \\
\hline The question about what is & .919 & \\
\hline
\end{tabular}




\begin{tabular}{|c|c|c|}
\hline Indicators & $\begin{array}{l}\text { Outer } \\
\text { Loadings }\end{array}$ & AVE \\
\hline $\begin{array}{l}\text { ethical for everyone will } \\
\text { never be answered (R5) }\end{array}$ & & \\
\hline $\begin{array}{l}\text { Moral standards are simple } \\
\text { rules used to guide } \\
\text { yourself. (R6) }\end{array}$ & .735 & \\
\hline $\begin{array}{l}\text { Rigid codification of } \\
\text { ethical codes which is used } \\
\text { to prevent certain actions } \\
\text { can block relationships } \\
\text { and adaptation between } \\
\text { individuals (R8) }\end{array}$ & .729 & \\
\hline $\begin{array}{l}\text { Dysfunctional Actions } \\
\text { (BD) }\end{array}$ & & .542 \\
\hline $\begin{array}{l}\text { Review documents } \\
\text { superficially }(\mathrm{BD} 3)\end{array}$ & .734 & \\
\hline $\begin{array}{l}\text { Failed to examine the } \\
\text { accounting principle used } \\
\text { by clients (BD4) }\end{array}$ & .772 & \\
\hline $\begin{array}{l}\text { Reduce the number of } \\
\text { audit procedures based on } \\
\text { logical reasons (BD5) }\end{array}$ & .732 & \\
\hline Premature sign-off (BD6) & .704 & \\
\hline $\begin{array}{l}\text { Auditors Acceptance of } \\
\text { dysfunctional behaviour } \\
\text { (MPD) }\end{array}$ & & .532 \\
\hline $\begin{array}{l}\text { Premature sign-off, } \\
\text { because they believed that } \\
\text { the existing audit } \\
\text { procedures wouldn't } \\
\text { produce finding, because } \\
\text { there were no problems } \\
\text { with client's systems or } \\
\text { documents in previous } \\
\text { audit (MPD1) }\end{array}$ & .739 & \\
\hline $\begin{array}{l}\text { Premature sign-off, } \\
\text { because the auditor was } \\
\text { convinced there were no } \\
\text { more audit steps needed to } \\
\text { be taken to find out the } \\
\text { client's faults. (MPD3) }\end{array}$ & .786 & \\
\hline $\begin{array}{l}\text { Underreporting of time } \\
\text { because it can increase the } \\
\text { chances of promotion } \\
\text { (MPD 4) }\end{array}$ & .644 & \\
\hline
\end{tabular}




\begin{tabular}{lrrr}
\hline Indicators & & $\begin{array}{l}\text { Outer } \\
\text { Loadings }\end{array}$ & AVE \\
\hline \multicolumn{2}{l}{ Underreporting } & of time & .740 \\
because it's & leaders' & \\
advice or & command & \\
(MPD6) & & & \\
\hline
\end{tabular}

\subsubsection{Discriminant Validity}

Table 3. shows that the discriminant validity of this research model is good because the square root of AVE for each construct is greater than the correlation between constructs in this model

\subsection{Hypothesis Testing}

Table IV shows that ethical environment was found to be statistically influential on auditor actions and acceptance for dysfunctional behavior. The effect of organization's ethical environment on dysfunctional actions has a significance value of $10 \%$ with a coefficient of .416. The effect of organization's ethical environment on auditor's acceptance for dysfunctional behavior has a significance value of $.039 \leq .1$ with a coefficient of -.381 . The implementation of ethical codes and compliance to authorities have a significant positive effect on auditor acceptance for dysfunctional behavior. Effect of implementation of ethical code of auditors on the acceptance for dysfunctional behavior has a significance value of .012 $\leq .1$ and a coefficient of .552. Effect of compliance to authority of auditors acceptance of dysfunctional behavior has a significance value of $.009 \leq .1$ with a coefficient of .434 . It can be interpreted that the first and second hypotheses can be accepted. Organizational ethical culture has an influence on auditor actions and acceptance for dysfunctional behavior.

Table 3. Fornel-Lacker Criterion

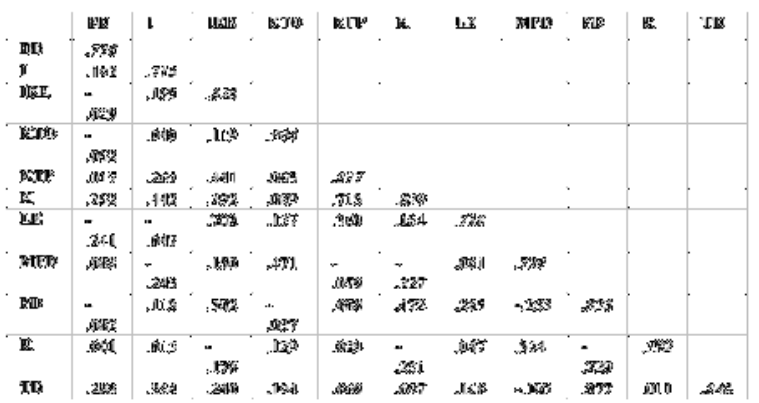

Table 4. Path-Coefficient-Bootstrapping

\begin{tabular}{llll}
\hline Description & $\mathbf{O}$ & $\begin{array}{l}\text { t- } \\
\text { value }\end{array}$ & p-value \\
\hline Effect of Personal Value to Moral Philosophy & & & \\
\hline Conservation $\rightarrow$ Idealism & $\mathbf{. 4 7 3}$ & $\mathbf{2 . 0 9 7}$ & $\mathbf{. 0 3 7}$ \\
\hline Conservation $\rightarrow$ Relativism & - & $\mathbf{2 . 7 7 1}$ & $\mathbf{. 0 0 6}$ \\
& $\mathbf{. 5 9 6}$ & & \\
\hline Self-transcendence $\rightarrow$ Idealism & .076 & .292 & .770 \\
\hline
\end{tabular}




\begin{tabular}{|c|c|c|c|}
\hline Self-transcendence $\rightarrow$ Relativism & .152 & .673 & .501 \\
\hline Self-enhancement $\rightarrow$ Idealism & -105 & .409 & .682 \\
\hline Self-enhancement $\rightarrow$ Relativism & 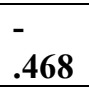 & 2.308 & .021 \\
\hline Openness to change $\rightarrow$ Idealism & -048 & .149 & .882 \\
\hline Openness to change $\rightarrow$ Relativism & .673 & 2.595 & .010 \\
\hline \multicolumn{4}{|l|}{ Effect of Moral Philosophy to Dysfunctional Actions } \\
\hline Idealism $\rightarrow$ Dysfunctional act & .046 & .248 & .804 \\
\hline Relativism $\rightarrow$ Dysfunctional act & .172 & .951 & .342 \\
\hline \multicolumn{4}{|c|}{ Effect of Moral Philosophy to Auditors Acceptance of dysfunctional behaviour } \\
\hline $\begin{array}{lllll}\begin{array}{l}\text { Idealism } \rightarrow \\
\text { behaviour }\end{array} & \text { Auditor } & \text { acceptance } & \text { of } & \text { dysfunctional } \\
\end{array}$ & -.327 & 2.436 & .015 \\
\hline $\begin{array}{l}\begin{array}{l}\text { Relativism } \rightarrow \\
\text { behaviour }\end{array} \\
\end{array}$ & .350 & 2.286 & .023 \\
\hline \multicolumn{4}{|l|}{ Effect of Organizational Ethical Culture to Dysfunctional Actions } \\
\hline Ethical environment $\rightarrow$ Dysfunctional act & .416 & 1.642 & .101 \\
\hline Implementation of ethical code $\rightarrow$ Dysfunctional act & .336 & 1.415 & .158 \\
\hline Compliance to authority $\rightarrow$ Dysfunctional act & $\begin{array}{l}- \\
.134\end{array}$ & .821 & .412 \\
\hline \multicolumn{4}{|c|}{$\begin{array}{l}\text { Effect of Organizational Ethical Culture to Auditors Acceptance of dysfunctiona } \\
\text { behaviour }\end{array}$} \\
\hline $\begin{array}{lllll}\begin{array}{l}\text { Ethical } \\
\text { dysfunctional behaviour }\end{array} & \begin{array}{c}\text { environment } \rightarrow \\
\text { Auditors }\end{array} & \text { acceptance } & \text { of } \\
\end{array}$ & $\begin{array}{ll}- \\
.381\end{array}$ & 2.067 & .039 \\
\hline $\begin{array}{l}\text { Implementation of ethical code } \rightarrow \text { Auditors acceptance of } \\
\text { dysfunctional behaviour }\end{array}$ & .552 & 2.509 & .012 \\
\hline $\begin{array}{l}\text { Compliance to authority } \rightarrow \text { Auditors acceptance of } \\
\text { dysfunctional behaviour }\end{array}$ & .434 & 2.608 & .009 \\
\hline \multicolumn{4}{|l|}{ Effect of Personal Value to Dysfunctional Actions } \\
\hline Cons & .383 & 1.251 & .212 \\
\hline nce $\rightarrow$ Dysfunctional & .350 & 1.307 & .192 \\
\hline Self-enhancement $\rightarrow$ Dysfunctional act & -096 & .380 & .704 \\
\hline Openness to change $\rightarrow$ Dysfunctional act & -402 & .950 & .343 \\
\hline \multicolumn{4}{|c|}{ Effect of Personal Value to Auditors Acceptance of dysfunctional behaviour } \\
\hline 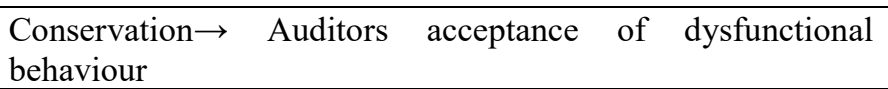 & -.038 & .149 & .882 \\
\hline $\begin{array}{l}\text { Self-transcendence } \rightarrow \text { Auditors acceptance of dysfunctional } \\
\text { behaviour }\end{array}$ & -141 & .680 & .497 \\
\hline $\begin{array}{l}\text { Self-enhancement } \rightarrow \text { Auditors acceptance of dysfunctional } \\
\text { behaviour }\end{array}$ & .285 & 1.917 & .056 \\
\hline Openness to change $\rightarrow$ Auditors acceptance of dysfunctional & .184 & .587 & .558 \\
\hline
\end{tabular}




\begin{abstract}
behaviour
Note: has a statistically significant influence

By using a significance value of $1 \%, 5 \%$, and $10 \%$, found that there was no personal value effected the dysfunctional auditor's actions. The effect of self-enhancement was found to have a significant negative effect on auditor acceptance for dysfunctional behavior with a significance value of $.056 \leq .1$ and a coefficient of -.285 . It can be interpreted that the fifth hypothesis of this study is rejected, while the sixth hypothesis is accepted. Personal value has no effect on auditor dysfunctional actions, but affects the auditor's acceptance for dysfunctional behavior.

Conservation has a significant positive effect with a significance value of $.037 \leq .1$ and a coefficient of .473. Conversely, conservation has a significant negative effect on relativism with a significance of $.006 \leq .101$ and coefficient of -.596 . Self-enhancement has a significant negative effect on relativism with a significance of $.021 \leq .1$ and a coefficient of -.468. Openess to change has a significant positive effect on relativism with a significance value of $.010 \leq .1$ and a coefficient of .673. It can be interpreted that the seventh hypothesis in this study was accepted. Personal value has an effect on auditors' moral philosophy.

Moral philosophy has no significant effect on auditors' dysfunctional actions with a significance value of $.804 \geq .1$ and a coefficient of -.046 for the idealism and significance of $.342 \geq .1$ with a coefficient of .172 for relativism. Idealism has a significant negative effect on auditor acceptance for dysfunctional behavior with a significance value of $.015 \leq .1$ and a coefficient of -.372. Relativism has a significant positive effect on auditor acceptance for dysfunctional behavior with a significance value of $.023 \leq .1$ and a coefficient of .350 . This study failed to support the eighth hypothesis and successfully supported the ninth hypothesis. Auditors moral philosophy is found to have no effect on auditor dysfunctional actions, but has an influence on auditor acceptance for dysfunctional behavior.
\end{abstract}

\title{
4. Conclusions
}

Organizational ethical culture has a direct effect on auditor actions and acceptance for dysfunctional behavior without being mediated by personal values and auditors' moral philosophy. Organizational ethical culture is able to prevent auditor actions and acceptance for dysfunctional behavior, but doesn't make auditors belief (personal values and moral philosophy) changes about actions and acceptance to these behaviors. There are no personal characteristics, i.e. personal values and moral philosophies that influence auditors' dysfunctional actions. The auditors' dysfunctional actions are only influenced by organizational characteristics, i.e. the ethical environment of organization. However, these personal characteristics have an influence on auditors' acceptance for dysfunctional behavior. Strong ethical environment will be able to overcome auditor actions and acceptance for dysfunctional behavior. But implementation of ethical code and compliance to authority has an influence that is comparable to auditors' acceptance for dysfunctional behavior. Conservation has a negative influence on auditors' acceptance for dysfunctional behavior through idealism. The results also show that self-enhancement has a direct negative effect on auditors' acceptance for dysfunctional behavior. Auditor who tend to have moral philosophy of idealism and not relativism is auditor having personal value of conservatism and selfenhancement. While the auditor who tend to relativism is the auditor who has a personal value of openness to change. Auditors who have a moral philosophy of relativism will tend to accept dysfunctional behavior, while the idealism auditor will tend to reject such behavior. 


\section{References}

[1] Aprilia, E. R. and Pangestuti, E. (2017) 'Pengaruh daya tarik wisata dan fasilitas layanan terhadap kepuasan wisatawan di pantai balekambang kabupaten malang', Jurnal Administrasi Bisnis (JAB), 51(2), pp. 16-21.

[2] Dirsmith, M. W. and Covaleski, M. A. (1985) 'Informal communications, nonformal communications and mentoring in public accounting firms', Accounting, Organizations and Society, 10(2), pp. 149-169. doi: 10.1016/0361-3682(85)90013-3.

[3] Donnelly, D. P., Quirin, J. J. and O'Bryan, D. (2003) 'Auditor Acceptance of Dysfunctional Audit Behavior: An Explanatory Model Using Auditors' Personal Characteristics', Behavioral Research in Accounting, 15, pp. 87-100. doi: http://aaapubs.org/loi/bria.

[4] Fogarty, T. J. (1992) 'Organizational socialization in accounting firms: A theoretical framework and agenda for future research', Accounting, Organizations and Society, 17(2), pp. 129-149. doi: 10.1016/0361-3682(92)90007-F.

[5] Forsyth, D. R. (2013) 'Judging the morality of business practices: The influence of personal moral philosophies', Journal of Business Ethics, 11, pp. 461-470. doi: 10.1007/978-94-007-4126-3 12.

[6] Hunt, S. D. and Vitell, S. J. (2006) 'The general theory of marketing ethics: A revision and three questions', Journal of Macromarketing, 26(2), pp. 143-153. doi: 10.1177/0276146706290923.

[7] Karim, M. S., Paino, H., Jabar, F. A., Pauzi, N. F. M. and Bakar, S. A. N. A. (2015) 'Factors contributing to premature sign-off of audit procedure: Evidence from Malaysia', Advanced Science Letters, 21(5), pp. 1243-1246. doi: 10.1166/asl.2015.5991.

[8] Otley, D. T. and Pierce, B. J. (1996) 'Auditor time budget pressure: Consequences and antecedents', Accounting, Auditing \& Accountability Journal, 9(1), pp. 31-58. doi: 10.1108/09513579610109969.

[9] Rallapalli, K. C., Vitell, S. J. and Szeinbach, S. (2000) 'Marketers' norms and personal values: An empirical study of marketing professionals', Journal of Business Ethics, 24(1), pp. 65-75. doi: 10.1023/A:1006068130157.

[10] Satava, D., Caldwell, C. and Richards, L. (2006) 'Ethics and the auditing culture: Rethinking the foundation of accounting and auditing', Journal of Business Ethics, 64(3), pp. 271-284. doi: 10.1007/s10551-005-0556-y.

[11] Schein, E. H. and Schein, P. (2006) Organizational Culture and Leadership. John Wiley \& Sons, Ltd.

[12] Schwartz, S. H. (1992) 'Universals in the content and structure of values', Advances in Experimental Social Psychology, 25, pp. 1-65. doi: 10.1016/S0065-2601(08)60281-6.

[13] Schwartz, S. H. and Bilsky, W. (1987) 'Toward A Universal Psychological Structure of Human Values', Journal of Personality and Social Psychology, 53(2), pp. 550-560. doi: $10.1037 / 0022-3514.53 .3 .550$.

[14] Suhayati, E. (2012) 'the Influence of Audit Fee , Audit Time Budget Pressure and Public Behavior and It' S Implication on Audit Quality Survey on " Small "', Journal of Global Management, 4(1).

[15] Svanberg, J. and Öhman, P. (2013) 'Auditors' time pressure: does ethical culture support audit quality?', Managerial Auditing Journal. Emerald Group Publishing Limited, 28(7), pp. 572-591. doi: 10.1108/MAJ-10-2012-0761.

[16] Sweeney, B., Pierce, B. and Arnold, D. F. (2013) 'The impact of perceived ethical 
intensity on audit-quality-threatening behaviours', Accounting and Business Research, 43(2), pp. 112-137. doi: 10.1080/00014788.2013.771571.

[17] Treviño, L. K., Butterfield, K. D. and McCabe, D. L. (1998) 'The Ethical Context in Organizations', Business Ethics Quarterly. Edited by D. G. Arnold. Philosophy Documentation Center, 8(3), pp. 447-476. doi: 10.5840/10.2307/3857431.

[18] Zarei, R., Esmaeeli, A. and Zarei, S. (2016) 'Studying the influential factors on ethics in accounting and auditing regarding personal dimensions', International Business Management, pp. 1141-1150. doi: 10.3923/ibm.2016.1141.1150. 